\title{
A new combined inorganic-organic flocculant (CIOF) as a performance enhancer for aerated submerged membrane bioreactor
}

\author{
Tien Thanh Nguyen, Wenshan Guo, Huu Hao Ngo, Saravanamuthu \\ Vigneswaran* \\ School of Civil and Environmental Engineering, University of Technology Sydney, \\ Broadway, NSW 2007, Australia \\ * Corresponding author, Tel: +61-2-9514-2641, Fax: + 61-2-9514-2633, \\ E-mail: S.Vigneswaran@uts.edu.au
}

\begin{abstract}
In this study, a new combined inorganic-organic flocculant (CIOF) of $\mathrm{FeCl}_{3}$ and membrane performance enhancer (MPE50) was prepared and added to an aerated submerged membrane bioreactor (SMBR). The effects of CIOF on the performance of an aerated submerged membrane bioreactor (SMBR) were evaluated. The results indicated that the SMBR with CIOF addition could remove almost $100 \%$ total phosphate while eliminating over $90 \%$ ammonia $\left(\mathrm{NH}_{4}-\mathrm{N}\right)$ and dissolved organic carbon (DOC) during an 80-day of operation. The respiration tests revealed that the specific oxygen uptake rate (SOUR) was stable around 1.5-2.0 $\mathrm{mg} \mathrm{O} / \mathrm{g}$ MLvss.h. The sludge volume index (SVI) of less than $100 \mathrm{~mL} / \mathrm{g}$ during the operation showed the importance of CIOF on the improvement of settling properties of the sludge. Soluble carbohydrate concentration was also well correlated with DOC of the supernatant. CIOF was
\end{abstract}


successful in the reduction of fouling of membrane as the membrane was only chemically cleaned after 53 days of operation.

Keywords: Submerged membrane bioreactor, ferric chloride, membrane performance enhancer (MPE50), organic and nutrient removals

\section{Introduction}

Among membrane processes, membrane bioreactor (MBR) technology is an innovative and promising option for wastewater treatment and reuse. It has been considered as one of the most favourable processes for water reclamation with many outstanding advantages over the conventional activated sludge systems. However, MBR has some drawbacks, in particular membrane fouling. Membrane fouling deteriorates the permeability of the membrane and consequently increases the energy consumption in MBR. In addition, due to this problem, operational and maintenance cost of the MBR are high. Therefore, it is necessary to develop an effective and economical method of preventing or reducing membrane fouling [1].

The coagulant addition to minimise membrane fouling has been developed by several researchers. Coagulants are generally added during water and wastewater treatment to remove colloidal and suspended solids through their aggregation to larger flocs [2]. It has been reported that coagulants such as $\mathrm{FeCl}_{3}$ and alum were effective in enhancing filterability of mixed liquor and controlling membrane fouling [3,4]. Ferric chloride has been tested in pre-coating and flocculation experiments to retard membrane fouling [3]. These studies revealed that ferric chloride was efficient in removing nonbiodegradable materials without stressing the microorganisms. Zhang et al. [5] 
demonstrated that the addition of $\mathrm{FeCl}_{3}$ to the $\mathrm{MBR}$ system at the optimal concentration improved the filterability of the mixed sludge and mitigated the membrane fouling. The results indicated that the optimal ferric chloride concentration affected the molecular weight distribution of the soluble microbial product (SMP) and particle size distribution of the flocs in the hybrid MBR, reducing the fraction of larger molecular weight higher than $10 \mathrm{kDa}$ in the SMP and the 1-10 $\mu \mathrm{m}$ particles in the flocs. Moreover, the element analysis of extracellular polymeric substances (EPS) implied that the addition of Fe(III) to the MBR system bridged the negatively charged groups of the components of the EPS and replaced other elements through ion exchange. Song et al. [6] evaluated the use of ferric chloride in MBR application. It was able to largely improve the phosphorus removal as well as the filtration resistance.

Applying polymer to improve the performance of MBR has also been studied. Various synthetic and natural polymers have been tested in fouling control. Yoon et al. [7] indicated that the total solids in bioreactor could be raised to $50,000 \mathrm{mg} / \mathrm{L}$ without immediate membrane fouling with the addition of $2200 \mathrm{mg} / \mathrm{L}$ of a cationic polymer. After testing a total of 30 different additives, Iversen et al. [8] have shown that some of the tested additives were able to significantly reduce the concentration of SMP. A new membrane performance enhancer (MPE50 ${ }^{\mathrm{TM}}$ ) was first introduced by Yoon and Collins [9] as a commercial product of Nalco Company. Their study showed that with $400 \mathrm{ppm}$ of MPE50, a full scale municipal MBR plant $\left(2,300 \mathrm{~m}^{3} / \mathrm{d}\right)$ could be operated at a higher flux of $47.25 \mathrm{~L} / \mathrm{m}^{2} . \mathrm{h}$, which is $39 \%$ above the critical flux $\left(34 \mathrm{~L} / \mathrm{m}^{2} . \mathrm{h}\right)$, for one day without any significant permeability loss. Another advantage of MPE50 is that it did not negatively affect the overall aeration demand. Lab and pilot scale experiments with 
MPE50 addition have shown that the membrane fouling rates could significantly be reduced even under high flux conditions and the process could be operated at an extremely high suspended solid level, e.g. 50,000 mg/L [10]. In addition, permeate chemical oxygen demand (COD) was improved by approximately $30 \%$, whereas no toxic effects on bioactivity were found. This study also showed that MPE50 could reduce foaming in the anoxic tank. A study on the influence of MPE50 on membrane fouling mitigation in a MBR revealed that $50 \mathrm{mg} / \mathrm{L}$ of the polymer dosage was the optimum as it resulted in long filtration time [11]. Moreover, the soluble COD and soluble EPS concentrations in the MPE50 added MBR were lower than those in the control MBR (without MPE50). The biofilm structure investigation at the same transmembrane pressure (TMP) also exhibited that MPE50 addition achieved higher biofilm porosity and lower amount of attached biomass. Besides, Guo et al [12] proved that submerged MBR (SMBR) with MPE50 addition could significantly improve the sustainable flux and reduce membrane fouling. Furthermore, the system achieved high dissolved organic carbon (DOC) and COD removal efficiencies (>95\%), as well as outstanding $\mathrm{NH}_{4}-\mathrm{N}$ removal of over $95-98 \%$ and $\mathrm{PO}_{4}-\mathrm{P}$ removal of over $99 \%$ after 7 days operation. Koseoglu et al. [13] studied on the effects of different flux enhancing chemicals on the filterability and the fouling reduction of MBR. The results indicated that at their optimal dosages, the cationic polymers such as MPE50, MPL30 and KD452 provided 96, 80 and $74 \%$ reductions in fouling rates, respectively. Additionally, consistent with short term filtration test, cationic polymers performed well and increased critical flux value to above $50 \mathrm{~L} / \mathrm{m}^{2} . h$ levels. 
The objective of this study was to investigate the effect of a new combined CIOF of $\mathrm{FeCl}_{3}$ and MPE50 for SMBR in treating a synthetic wastewater. The performance of the SMBR was assessed in terms of organic and nutrient removal efficiencies, membrane fouling based on TMP development and sludge volume index (SVI). Microbial activity of activated sludge was evaluated in terms of specific oxygen uptake rate (SOUR).

\section{Materials and Method}

\subsection{Synthetic wastewater}

The experiments were conducted using a synthetic wastewater to avoid any fluctuation in the feed concentration and provide a continuous source of biodegradable organic pollutants such as glucose, ammonium sulfate and potassium dihydrogen orthophosphate. The synthetic wastewater used in this study represents high strength domestic wastewater (just after primary treatment process). The synthetic wastewater consists of DOC of 120-130 mg/L, COD of 330-360 mg/L, ammonium nitrogen $\left(\mathrm{NH}_{4}-\right.$ $\mathrm{N})$ of $12-15 \mathrm{mg} / \mathrm{L}$ and total phosphate $(\mathrm{T}-\mathrm{P})$ of $3.6-3.9 \mathrm{mg} / \mathrm{L}(\mathrm{COD}: \mathrm{N}: \mathrm{P}=100: 5: 1)$. The composition of synthetic wastewater used in this study is shown in Table 1 [14].

\section{Table 1}

Characteristics of the synthetic wastewater

\subsection{Flocculant}

MPE50 used in this experiment was obtained from Nalco Company. The combined flocculant CIOF was prepared by mixing ferric chloride and MPE50 at a ratio of $1: 1\left(2 \mathrm{~g}\right.$ of MPE50 with $100 \mathrm{~mL}$ of $\left.2 \% \mathrm{FeCl}_{3}\right)$. The CIOF was manually added to the activated sludge 2 times per day at a dosage of $30 \mathrm{mg} / \mathrm{L}_{\text {wastewater }}$. 


\subsection{SMBR set-up}

A polyethylene hollow fiber membrane module was used with the pore size of $0.1 \mu \mathrm{m}$ and the surface area of $0.05 \mathrm{~m}^{2}$ (Mitsubishi-Rayon, Japan). The effective volume of the bioreactor was $6 \mathrm{~L}$ and the filtration rate was maintained at $12 \mathrm{~L} / \mathrm{m}^{2} . \mathrm{h}$. The membrane was placed inside the reactor. Synthetic wastewater was pumped into the reactor using a feeding pump to control the feed rate while the effluent flow rate was controlled by a suction pump. A pressure gauge was used to measure the TMP and a soaker hose air diffuser was used to maintain the air flow rate. The SMBR was filled with the sludge from a local Wastewater Treatment Plant and acclimatised to synthetic wastewater. The initial mixed liquor suspended solids (MLSS) was $5 \mathrm{~g} / \mathrm{L}$. The experiment was conducted at room temperature, which was about $25^{\circ} \mathrm{C}$. Hydraulic retention time and organic loading rate of the system were 10 hours and $4.75 \mathrm{~g} \mathrm{COD} / \mathrm{d}$, respectively. No excess sludge was withdrawn during the experiment.

\subsection{Analysis}

DOC of the influent and effluent was measured using the Analytikjena Multi N/C 2000. The analysis of COD and measuring of MLSS and biomass (monitored as mixed liquor volatile suspended solids, MLVSS) were according to Standard Methods [15]. T-N and T-P were measured by photometric method using Spectroquant ${ }^{\circledR}$ Cell Test (NOVA 60, Merck). YSI 5300 Biological Oxygen Monitor was used to measure the SOUR. The oxygen consumption measurement can be achieved through the use of oxygen electrode with oxygen permeable Teflon membrane. Voltage generated from the 
reaction is proportional to the oxygen concentration of the sample and produces oxygen uptake during a period of 2-15 min.

\subsection{Membrane cleaning}

The fouled membrane was cleaned using both physical and chemical methods. The physical cleaning was adopted by providing 1 min backwash every $1 \mathrm{~h}$ at a

backwash rate of $30 \mathrm{~L} / \mathrm{m}^{2} . h$. The membrane was chemically cleaned on the $53^{\text {rd }}$ day when the TMP reached a value of $36 \mathrm{kPa}$. The chemical cleaning procedure is as follows: (i) the cake layer formed from activated sludge on fouled membrane was brushed off; (ii) the membrane was soaked in $2 \%$ citric acid solution for $2 \mathrm{~h}$; and (iii) the membrane was immersed for $2 \mathrm{~h}$ in $4 \% \mathrm{NaOH}$ and $0.4 \% \mathrm{NaOCl}$ solution.

\section{Results and discussion}

\subsection{Short-term SMBR with individual flocculant addition}

Short-term experiments were conducted to investigate the effects of the two individual flocculants $\left(\mathrm{FeCl}_{3}\right.$ and MPE50) on SMBR performance. Table 2 presents the comparison results of SMBR alone and SMBRs with flocculants' addition. As shown in Table 2, $\mathrm{FeCl}_{3}$ addition could slightly improve the reduction of DOC compared to SMBR alone, which led up to $97.6 \pm 0.7 \%$ removal, whereas the DOC removal with MPE50 (94.1 $\pm 1.9 \%)$ was slightly lower than that of SMBR alone $(96.5 \pm 0.3 \%)$. Both of the flocculants showed their potential for reducing membrane fouling. Compared to the membrane fouling rate of SMBR alone $(5 \mathrm{kPa} / \mathrm{d})$, the $\mathrm{FeCl}_{3}$ and MPE50 resulted in a lower membrane fouling rates of 1.3 and $3.3 \mathrm{kPa} / \mathrm{d}$, respectively. With regards to nutrient removal, flocculants improved the nitrification in the SMBR and MPE50 
yielded in the highest $\mathrm{NH}_{4}-\mathrm{N}$ removal efficiency of $75.2 \%$ during the 10 day- operation. Nevertheless, although T-N can be partially removed in aerobic SMBR (53.8\%) through the anoxic micro-zones in the centre of microbial flocs, $\mathrm{FeCl}_{3}$ only increased $7 \%$ of $\mathrm{T}-\mathrm{N}$ removal while MPE50 decreased the value to $34.9 \%$, indicating the synthetic organic polymer may have negative effect on denitrification. Moreover, MPE50 also exhibited an insignificant decrease in T-P removal. However, MPE50 enhanced the SOUR of the mixed liquor significantly (1.5 times than that of SMBR alone), which indicated that organic flocculant could improve the microbial activity. In addition, MPE50 also showed the lowest biomass growth rate of $0.15 \mathrm{~g} / \mathrm{d}$, resulting in the lowest sludge production.

\section{Table 2}

The performance of tested flocculants in 10-day submerged MBR experiment (filtration rate $10 \mathrm{~L} / \mathrm{m}^{2} \cdot \mathrm{h}$, initial MLSS $=5 \mathrm{~g} / \mathrm{L}$, backwash rate $=30 \mathrm{~L} / \mathrm{m}^{2} \cdot \mathrm{h}$, backwash $=2$ times per day for $2 \mathrm{~min}$ duration, influent $\mathrm{DOC}=135-160 \mathrm{mg} / \mathrm{L}, \mathrm{NH}_{4}-\mathrm{N}=16-19 \mathrm{mg} / \mathrm{L}, \mathrm{T}-\mathrm{N}$ $=17-22 \mathrm{mg} / \mathrm{L}, \mathrm{T}-\mathrm{P}=3.6-3.9 \mathrm{mg} / \mathrm{L}$ )

Based on the merits of each flocculant, $\mathrm{FeCl}_{3}$ and MPE50 were combined to be a new flocculant (CIOF) at a ratio of 1:1 to conduct a long-term experiment.

\subsection{Evaluation of CIOF as performance enhancer for SMBR}

\subsubsection{Organic and nutrient removals}

Organic and nutrient removals by the SMBR system with the addition of CIOF are shown in Fig. 1. The results show that over $95 \%$ of DOC was removed from the SMBR system with the effluent concentration of only 2-5 mg/L. Nutrients removal was investigated in terms of $\mathrm{NH}_{4}-\mathrm{N}, \mathrm{T}-\mathrm{N}$ and T-P removal. This system was successful in achieving phosphorus removal of almost 100\%. This high phosphorus removal 
efficiency was mainly due to two mechanisms, biological phosphorus removal and chemical precipitation. Biological phosphorus removal relies on the enrichment of the activated sludge system with phosphorus accumulating organisms (PAOs). Chemical precipitation of $\mathrm{P}$ is by the reaction between ferric ion and phosphorus in the wastewater to form ferric phosphate as precipitant. This system could also successfully remove $\mathrm{NH}_{4}-\mathrm{N}$ with an efficiency of $85-95 \%$. However, the total nitrogen removal was not significant. During the whole operation process, the system was constantly supplied with $10 \mathrm{~L}_{\text {air }} / \mathrm{min}$. With the biomass growth, the nitrification rapidly reduced due to the decrease in the dissolved oxygen (DO) in the suspension. Thus, T-N removal efficiency decreased from $75 \%$ at the beginning to only $8 \%$ after 35 days of operation. The systems then recovered back to yield T-N removal of $50-55 \%$ till the end of the experiment. This might be due to the occurrence of large size of sludge flocs in which the denitrification process may have taken place inside the biomass.

Fig. 1. DOC, $\mathrm{NH}_{4}-\mathrm{N}, \mathrm{T}-\mathrm{N}$ and T-P profiles of SMBR system (influent DOC $=120-130$ $\mathrm{mg} / \mathrm{L} ; \mathrm{NH}_{4}-\mathrm{N}=16-18 \mathrm{mg} / \mathrm{L} ; \mathrm{T}-\mathrm{N}=16-19 \mathrm{mg} / \mathrm{L} ; \mathrm{T}-\mathrm{P}=3.6-3.9 \mathrm{mg} / \mathrm{L}$; filtration flux = $12 \mathrm{~L} / \mathrm{m}^{2} . \mathrm{h}$; backwash rate $=36 \mathrm{~L} / \mathrm{m}^{2} . \mathrm{h}$, CIOF dosage $=30 \mathrm{mg} / \mathrm{L}$ )

\subsubsection{SOUR}

Oxygen uptake rate plays a crucial role in aerated activated sludge systems, as oxygen is required to remove both nitrogen and carbon. In an activated sludge process, oxygen uptake rate is influenced by several parameters such as MLSS concentration, wastewater type, mixing characteristics, the availability of substrates and nutrients and the presence of toxins. In this study, respiration test was conducted with the mixed liquor taken from the bioreactor periodically.

Fig. 2. Temporal variation of the SOUR and Fe (III) concentration of mixed liquor during the experiment 
The SOUR was 2.33 to $2.66 \mathrm{mg} \mathrm{O}_{2} / \mathrm{g}$ VSS.h from day 1 to day 3 (Fig. 2). It was increased to $4.5 \mathrm{mg} \mathrm{O}_{2} / \mathrm{g}$ VSS.h on day 5 and remained constant up to day 30 . This was followed by a slight drop on day 35 to $2.4 \mathrm{mg} \mathrm{\textrm {O } _ { 2 }} / \mathrm{g}$ VSS.h and remained steady from day 45 to the end of the experiment with the SOUR value of 1.56 to $2.07 \mathrm{mg} \mathrm{O} / \mathrm{g}$ VSS.h. The decline of the SOUR may be due to the accumulation of $\mathrm{FeCl}_{3}$ in the system. In this study, Fe (III) concentration was analysed in the supernatant. The result indicated that at the beginning of the experiment, the Fe (III) concentration was around 11.9-12.3 mg/L. It then accumulated and increased up to $44 \mathrm{mg} / \mathrm{L}$ on day 40 and 55 . Zhang et al. [16] observed the inhibiting effect of ferric salts on microbial activity in membrane bioreactors. Their study showed a decrease of microbial activity for Fe(III) concentration between $20-60 \mathrm{mg} / \mathrm{L}$. The similar trend was also observed in the present study. Similarly, Iversen et al. [17] investigated the impacts of several membrane flux enhancers on activated sludge respiration. Their results also reported that the lower SOUR value was observed with $\mathrm{FeCl}_{3}$ as compared to chitosans, PAC or polymers. There was no clear explanation regarding this negative effect with the literature, and the reason for this is still unclear.

\subsubsection{SVI}

SVI is widely used for characterising sludge settleability. Fig. 3 shows the variation of SVI with MLSS concentration in the SMBR system. The SVI varied between 38.6 to $64.2 \mathrm{~mL} / \mathrm{g}$. In the initial stage of operation, SVI showed a gradual increase along with the growth of biomass; however, after 35 days, the SVI stabilized even at high biomass concentration. This indicates the dependence of SVI on MLSS 
mainly during the initial phase. The SVI also shows a linear relationship with MLSS during the first 35 days $\left(\mathrm{r}_{\mathrm{p}}=0.9788\right.$ significant at 0.05 level $)$. There was no correlation between them after the day 35. Other authors have also reported limited dependence of SVI on biomass concentration in complete sludge retention MBRs [18].

Fig. 3. SVI and MLSS profiles of the SMBR system

In the present study, SVI value was always below $100 \mathrm{~mL} / \mathrm{g}$, indicating good settling properties of the sludge. High SVI is normally attributed to growth of filamentous bacteria. Several authors have reported that the presence of metal ions such as calcium, magnesium or iron ions in the feed contributes to the control of sludge bulking [19]. Therefore, CIOF used in this study did not lead to the growth of filamentous microorganisms which is resulted in low SVI. In order to clarify this assumption, the SVI during the first 3 days was compared with the SVI of blank-MBR. The result showed the SVI was higher in the experiment without flocculants addition after 3 days operation. This clearly indicates that the flocculants have positive effect on controlling SVI.

\subsubsection{Soluble EPS in supernatant}

There are various biological, physical and chemical factors affecting membrane fouling in the activated sludge. To elucidate the fouling tendency, the quantity of EPS was analysed. EPS matrix is heterogeneous, in which polymeric material such as carbohydrates and proteins, lipids and nucleic acids have been found. However, the sum of carbohydrates and proteins is considered to represent the EPS because these were the dominant components found in the extracted EPS [20,21].

Fig. 4. Protein and carbohydrate concentration of soluble EPS 
In an MBR, the quantity and quality of EPS is influenced by the process design and operational factors such as type of feed (wastewater), MLSS concentration, SRT, etc. Moreover, the different growth phases of microbes and the fluctuations in feeding or sludge wasting also affect the EPS concentration in the reactor [22,23].

Fig. 4 presents the soluble proteins and carbohydrates concentration in the system. It is evident that proteins are the dominant component in the soluble EPS isolated from activated sludge. Protein concentration varied from $23.33 \mathrm{mg} / \mathrm{L}$ (first day) to $38.67 \mathrm{mg} / \mathrm{L}\left(10^{\text {th }}\right.$ day) whereas carbohydrate concentration was only $0.47-9.07$ mg/L. Satyawali et al. [24] have also reported the higher proteins concentration in soluble EPS. In general, carbohydrates are extracellular components synthesized for specific function, while proteins can exist in the extracellular polymer network due to the excretion of intracellular proteins/enzymes or cell lysis [25]. Additionally, EPS was the highest at day 10 and 15, reflecting the increase of TMP from day 0 to day 15 (4 $\mathrm{kPa}$ to $20 \mathrm{kPa}$ ). During next 10 days, from day 20 to day 30, EPS remained steady, corresponding to a stable TMP value at around $20-21 \mathrm{kPa}$. Nevertheless, after 30 days of operation, there was no relationship between soluble EPS and TMP. During this period soluble EPS kept constant while TMP gradually increased.

Fig. 5 Correlation of soluble carbohydrates and DOC in the supernatant

Fig. 5 shows the relationship between soluble carbohydrate concentration and the DOC concentration in the supernatant. It can be observed that soluble carbohydrate concentration was well correlated with DOC values $\left(\mathrm{R}^{2}=0.9234\right)$. Previously, several 
authors have also reported the correlation between these two parameters; however, the R-squared values were not high [26]. This result shows the importance of the measurement of supernatant DOC for MBR monitoring. In contrast, such a correlation was not found between soluble proteins and DOC in the supernatant, between turbidity of supernatant and soluble carbohydrates or proteins.

\subsubsection{TMP development}

Fig. 6 shows the TMP of the experiments with and without flocculant addition. The TMP development was very high without flocculant addition as compared to the flocculant addition. TMP increased gradually during first 20 days of operation with a TMP development rate of $1 \mathrm{kPa} / \mathrm{d}$. The TMP remained constant at around $20-21 \mathrm{kPa}$ for the next 10 days. This followed by the increase up to $36 \mathrm{kPa}$. After the chemical cleaning on day 53 , the TMP dropped to $15 \mathrm{kPa}$. This was followed by a mild increase to $23 \mathrm{kPa}$ till day 70 and kept constant at $24 \mathrm{kPa}$ up to the end of the experiment. Interestingly, TMP increased only by $2 \mathrm{kPa}$ during this period while the MLSS concentration was relatively high during last 15 days of operation (around 16.55-17.85 $\mathrm{mg} / \mathrm{L})$. This result shows that the system could maintain at high activated sludge concentration without any significant effect on increasing TMP.

Fig. 6. TMP development of the SMBR systems with and without CIOF addition (Filtration flux $=12 \mathrm{~L} / \mathrm{m}^{2} . \mathrm{h}$; backwash rate $=36 \mathrm{~L} / \mathrm{m}^{2} . \mathrm{h}$, backwash 1 min every $1 \mathrm{hr}$ )

\subsection{Comparison between CIOF and individual flocculant}

Comparative results of CIOF and individual flocculant are summarised in Table 3. The average DOC removal efficiency was $98.2 \%$ when using CIOF, it was $0.6-$ $4.1 \%$ higher comparing to individual flocculant. The better performance of CIOF was also achieved in terms of T-P removal efficiency with the improvement of $0.1-4.4 \%$. 
The significant enhancement was addressed from $73.8-75.2 \%$ to $91.3 \%$ in $\mathrm{NH}_{4}-\mathrm{N}$ removal, showing the advantages of CIOF. In addition, with the biomass growth rate of only $0.16 \mathrm{~g}$ /day, the combined flocculant might be considered as a option for minimisation the excess sludge production. Furthermore, the CIOF was successful in reducing membrane fouling rate, with $58-83 \%$ less as compared with individual flocculant. These above comparisons demonstrated the advantages of CIOF in terms of pollutant removal, controlling sludge production and reducing membrane fouling.

Table 3

Comparison between CIOF and individual flocculant (FeCl3 and MPE50) (filtration rate $10 \mathrm{~L} / \mathrm{m} 2 . \mathrm{h}$, backwash rate $=30 \mathrm{~L} / \mathrm{m} 2 . \mathrm{h}$, initial MLSS $=5 \mathrm{~g} / \mathrm{L}$, influent DOC $=135$ $160 \mathrm{mg} / \mathrm{L}, \mathrm{NH} 4-\mathrm{N}=16-19 \mathrm{mg} / \mathrm{L}, \mathrm{T}-\mathrm{N}=17-22 \mathrm{mg} / \mathrm{L}, \mathrm{T}-\mathrm{P}=3.6-3.9 \mathrm{mg} / \mathrm{L}$ )

\section{Conclusions}

The effect of a CIOF on the performance of a long-term aerated SMBR was studied in detail. The addition of CIOF to SMBR was significantly improved both organic and nutrient removals. In addition, the CIOF could also maintain a good microbial activity with a stable SOUR. A stable SVI and soluble carbohydrate concentration and a low TMP development rate also supported the importance of CIOF on the reduction of membrane fouling. Further study on the optimization of $\mathrm{FeCl}_{3}$ and MPE50 and the characterization of this CIOF for the in-depth understanding of fundamental mechanisms is essential.

\section{Acknowledgements}

This research was funded by DEST International Science Linkages Competitive Grant. The authors are also grateful for the support of UTS Chancellor's Postdoctoral Research Fellowship and UTS Early Career Researcher Grants. 


\section{References}

[1] W. Yang, N. Cicek, J. Ilg, State-of-the-art of membrane bioreactors: Worldwide research and commercial applications in North America, J. Membr. Sci. 270 (2006) 201-211.

[2] Wu. J, Chen. F, Huang. Xia, Geng. W, Wen. X, Using inorganic coagulants to control membrane fouling in a submerged membrane bioreactor, Desalination 197 (2006) $124-136$.

[3] Y. Zhang, D. Bu, C.G. Liu, X. Luo, P. Gu, Study on retarding membrane fouling by ferric salts dosing in membrane bioreactors, IWA Special Conference, 2004.

[4] J.C. Lee, J.S. Kim, I.J. Kang, M.H. Cho, P.K. Park, C.H. Lee, Potential and limitations of alum or zeolite addition to improve the performance of a submerged membrane bioreactor, Water Sci. Technol. 43 (2001) 59 - 66.

[5] H.F. Zhang, B.S. Sun, X.H. Zhao, Z.H. Gao, Effect of ferric chloride on fouling in membrane bioreactor, Sep. Purif. Technol. 63 (2008) 341 - 347.

[6] K.G. Song, Y. Kim, K.H. Ahn, Effect of coagulant addition on membrane fouling and nutrient removal in a submerged membrane bioreactor, Desalination 221 (2008) $467-474$

[7] S.H. Yoon, J.H. Collins, D. Musale, S. Sundararajan, S.P. Tsai, G.A. Hallsby, J.F. Kong, J. Koppes, P. Cachia, Effects of flux enhancing polymer on the characteristics of sludge in membrane bioreactor process, Water Sci. Technol. 51 (2005) 151.

[8] V. Iversen, L. Bonnet, A. Drews, B. Lesjean, M. Kraume, Can we control the fouling with flux enhancing chemicals?, Proceedings of EUROMBRA Workshop 
"Biofouling in Membrane Systems", Trondheim, July 11-12, 2006, ISBN 82-7598065-8.

[9] S.H. Yoon, J.H. Collins, A novel flux enhancing method for membrane bioreactor process using polymer, Desalination 191 (2005) $52-61$.

[10] J.H. Collins, S.H. Yoon, D. Musale, J.F. Kong, J. Koppes, S. Sundararajan, S.P. Tsai, G.A. Hallsby, P. Cachia, K. Kronoveter, Membrane performance enhancer evaluations on pilot and full scale membrane bioreactors, Water Environ. J. 20 (2006) $43-47$.

[11] W.N. Lee, I.S. Chang, B.K. Hwang, C.H. Lee, X. Huang, Changes in biofilm architecture with addition of membrane fouling reducer in membrane bioreactor, Process Biochem. 42 (2007) 655 - 661.

[12] W.S. Guo, S. Vigneswaran, H.H. Ngo, J. Kandasamy, S. Yoon, The role of the membrane performance enhancer in a membrane bioreactor: a comparison with other submerged membrane hybrid systems, Desalination 231 (2007) 305 - 313.

[13] H. Koseoglu, N.O. Yigit, V. Iversen, A. Drews, M. Kitis, B. Lesjean, M. Kraume, Effects of several different flux enhancing chemicals on filterability and fouling reduction of membrane bioreactor mixed liquors, J. Membr. Sci. 320 (2008) 57 64.

[14] W. Lee, S. Kang, H. Shin, Sludge characteristics and their contribution to microfiltration in submerged membrane bioreactors, J. Membr. Sci. 216 (2003) 217 $-227$.

[15] APHA, AWWA, and WEF, Standard Methods for the examination of Water and Wastewater, $20^{\text {th }}$ edition, American Public Health Association, Washington, DC, 1998. 
[16] Y. Zhang, D. Bu, C.G. Liu, X. Luo, P. Gu, Study on retarding membrane fouling by ferric salts dosing in membrane bioreactor, WEMT, Seoul, Korea, 2004.

[17] V. Iversen, H. Koseoglu, N.O. Yigit, A. Drews, M. Kitis, B. Lesjean, M. Kraume, Impacts of membrane flux enhancers on activated sludge respiration and nutrient removal in MBRs, Water Res. 43 (2009) 822-830.

[18] A. Pollice, C. Giordano, G. Laera, D. Saturno, G. Mininni, Physical characteristics of the sludge in a complete retention membrane bioreactor, Water Res. 41 (2007) $1832-1840$.

[19] Y.F. Tsang, S.N. Sin, H. Chua, Nocardia foaming control in activated sludge process treating domestic wastewater, Bioresour. Technol. 99 (2008) 3381-3388.

[20] R. Bura, M. Cheung, B. Liao, J. Finlayson, B.C. Lee, I.G. Droppo, G.G. Leppard, S.N. Liss, Composition of extracellular polymeric substances in the activated sludge floc matrix. Water Sci. Technol. 37 (1998) 325.

[21] B. Frølund, R. Palmgren, K. Keiding, P.H. Nielsen, Extraction of extracellular polymers from activated sludge using a cation exchange resin, Water Res. 30 (1996) 1749.

[22] A. Drews, C.H. Lee, M. Kraume, Membrane fouling - a review on the role of EPS, Desalination 200 (2006) $186-188$.

[23] Q.T.T. Thuy, C. Visvanathan, Removal of inhibitory phenolic compounds by biological activated carbon coupled membrane bioreactor, Water Sci. Technol. 53 (2006) $89-97$.

[24] Y. Satyawali, M. Balakrishnan, Effect of PAC addition on sludge properties in an MBR treating high strength wastewater, Water Res. 43 (2009) 1577 - 1588. 
[25] Z. Ying, G. Ping, Effect of powdered activated carbon dosage on retarding membrane fouling in MBR, Sep. Purif. Technol. 52 (2006) $154-160$.

[26] S. Lyko, T. Wintgens, D.A. Halbouni, S. Baumgarten, D. Tacke, K. Drensla, A. Janot, W. Dott, J. Pinnekamp, T. Melin, Long-term monitoring of a full-scale municipal membrane bioreactor - Characterisation of foulants and operational performance, J. Membr. Sci. 317 (2008) 78 - 87. 
Table 1

Characteristics of the synthetic wastewater

\begin{tabular}{ccc}
\hline Compound & Chemical formula & $\begin{array}{c}\text { Concentration } \\
(\mathrm{mg} / \mathrm{L})\end{array}$ \\
\hline Organics and nutrients & & \\
Glucose & $\mathrm{C}_{6} \mathrm{H}_{12} \mathrm{O}_{6}$ & 280 \\
Ammonium sulfate & $\left(\mathrm{NH}_{2}\right)_{2} \mathrm{SO}_{4}$ & 142 \\
Potassium phosphate & $\mathrm{KH}_{2} \mathrm{PO}_{4}$ & 26 \\
& & \\
Trace nutrients & & 0.368 \\
Calcium chloride & $\mathrm{CaCl}_{2} \cdot 2 \mathrm{H}_{2} \mathrm{O}$ & 5.070 \\
Magnesium sulfate & $\mathrm{MgSO}_{4} \cdot 3 \mathrm{H}_{2} \mathrm{O}$ & 0.275 \\
Manganese chloride & $\mathrm{MnCl}_{2} \cdot 4 \mathrm{H}_{2} \mathrm{O}$ & 0.440 \\
Zinc sulfate & $\mathrm{ZnSO}_{4} \cdot 7 \mathrm{H}_{2} \mathrm{O}$ & 0.391 \\
Cupric sulfate & $\mathrm{CuSO}_{4} \cdot 5 \mathrm{H}_{2} \mathrm{O}$ & 0.42 \\
Cobalt chloride & $\mathrm{CoCl}_{2} \cdot 6 \mathrm{H}_{2} \mathrm{O}$ & 1.26 \\
Sodium molybdate & $\mathrm{Na}_{2} \mathrm{MoO}_{4} \cdot 2 \mathrm{H}_{2} \mathrm{O}$ & 1.45 \\
dihydrate & $\mathrm{FeCl}_{3}$ & 30 \\
Ferric chloride anhydrous & & \\
Yeast extract & &
\end{tabular}


Table 2

The performance of tested flocculants in 10-day submerged MBR experiment (filtration rate $10 \mathrm{~L} / \mathrm{m}^{2} . \mathrm{h}$, initial MLSS = $5 \mathrm{~g} / \mathrm{L}$, initial MLVSS/MLSS $=0.87$, backwash rate $=30 \mathrm{~L} / \mathrm{m}^{2} . \mathrm{h}$, backwash $=2$ times per day for 2 min duration, influent DOC $=135-160 \mathrm{mg} / \mathrm{L}, \mathrm{NH}+\mathrm{N}$ $=16-19 \mathrm{mg} / \mathrm{L}, \mathrm{T}-\mathrm{N}=17-22 \mathrm{mg} / \mathrm{L}, \mathrm{T}-\mathrm{P}=3.6-3.9 \mathrm{mg} / \mathrm{L}$ )

\begin{tabular}{|c|c|c|c|c|c|c|c|c|}
\hline Flocculant & $\begin{array}{l}\text { Dosage } \\
\text { (g/day) }\end{array}$ & $\begin{array}{l}\text { DOC removal } \\
\text { efficiency }(\%)\end{array}$ & $\begin{array}{c}\text { SOUR } \\
\left(\mathrm{mg} \mathrm{O}_{2} / g\right. \\
\text { MLVSS.h })\end{array}$ & $\begin{array}{l}\text { Biomass } \\
\text { growth rate } \\
\text { (g/day) }\end{array}$ & $\begin{array}{c}\text { Membrane } \\
\text { fouling rate } \\
(\mathrm{kPa} / \text { day })\end{array}$ & $\begin{array}{c}\mathrm{NH}_{4}-\mathrm{N} \\
\text { removal } \\
\text { efficiency }(\%)\end{array}$ & $\begin{array}{l}\text { T-N removal } \\
\text { efficiency }(\%)\end{array}$ & $\begin{array}{c}\text { T-P removal } \\
\text { efficiency } \\
(\%)\end{array}$ \\
\hline $\begin{array}{l}\text { No } \\
\text { flocculant }\end{array}$ & - & $96.5 \pm 0.3$ & $3.00 \pm 0.64$ & 0.23 & 5.0 & 66.4 & 53.8 & 99.5 \\
\hline $\mathrm{FeCl}_{3}$ & 0.9 & $97.6 \pm 0.7$ & $4.11 \pm 0.44$ & 0.33 & 1.3 & 73.8 & 60.8 & 99.9 \\
\hline MPE50 & $\begin{array}{l}\text { Initial dose } \\
250 \\
\mathrm{mg} / \mathrm{L}_{\text {(reactor }} \\
\text { volume), then } \\
0.3 \mathrm{~g} / \text { day }\end{array}$ & $94.1 \pm 1.9$ & $4.50 \pm 0.41$ & 0.15 & 3.3 & 75.2 & 34.9 & 95.6 \\
\hline
\end{tabular}


Table 3

Comparison between CIOF and individual flocculant $\left(\mathrm{FeCl}_{3}\right.$ and MPE50) (filtration rate $10 \mathrm{~L} / \mathrm{m}^{2} . \mathrm{h}$, backwash rate $=30 \mathrm{~L} / \mathrm{m}^{2} . \mathrm{h}$, initial $\mathrm{MLSS}=5 \mathrm{~g} / \mathrm{L}$, influent DOC $\left.=135-160 \mathrm{mg} / \mathrm{L}, \mathrm{NH}_{4}-\mathrm{N}=16-19 \mathrm{mg} / \mathrm{L}, \mathrm{T}-\mathrm{N}=17-22 \mathrm{mg} / \mathrm{L}, \mathrm{T}-\mathrm{P}=3.6-3.9 \mathrm{mg} / \mathrm{L}\right)$

Individual flocculant

$\mathrm{CIOF}$

98.2

100

91.3

0.16

Membrane fouling rate $(\mathrm{kPa} / \mathrm{day})$
$95.6-99.9$

$73.8-75.2$

$0.15-0.33$

$1.30-3.30$
0.55
Percentage improvement when using CIOF (\%)

$0.1-4.4$

$16.1-17.5$

$58-83$ 


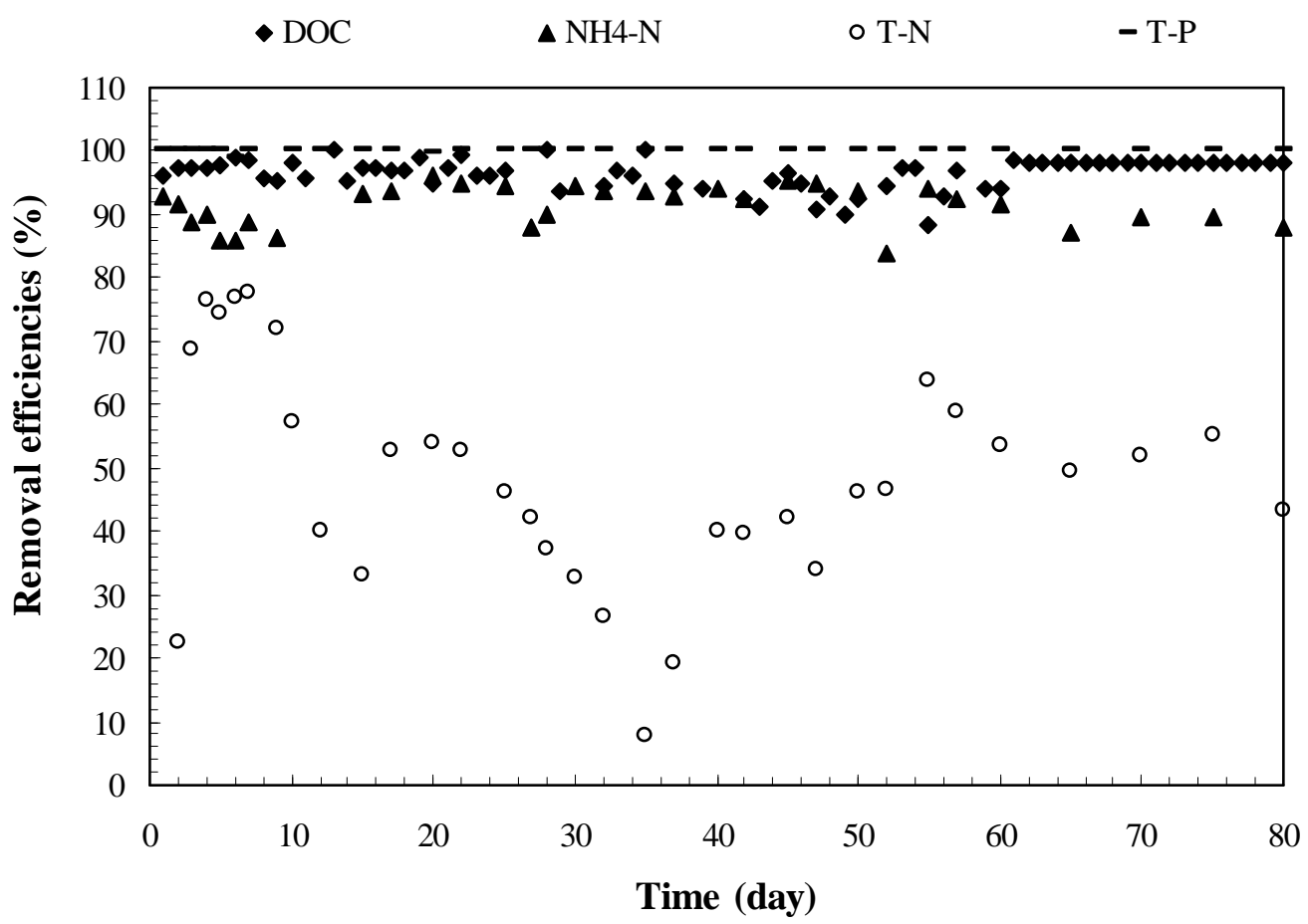

Fig. 1. DOC, $\mathrm{NH}_{4}-\mathrm{N}, \mathrm{T}-\mathrm{N}$ and T-P profiles of SMBR system (influent $\mathrm{DOC}=120-130$ $\mathrm{mg} / \mathrm{L} ; \mathrm{NH}_{4}-\mathrm{N}=16-18 \mathrm{mg} / \mathrm{L} ; \mathrm{T}-\mathrm{N}=16-19 \mathrm{mg} / \mathrm{L} ; \mathrm{T}-\mathrm{P}=3.6-3.9 \mathrm{mg} / \mathrm{L}$; filtration flux = $12 \mathrm{~L} / \mathrm{m}^{2} . \mathrm{h}$; backwash rate $=36 \mathrm{~L} / \mathrm{m}^{2} . \mathrm{h}$, CIOF dosage $=30 \mathrm{mg} / \mathrm{L}$ ) 


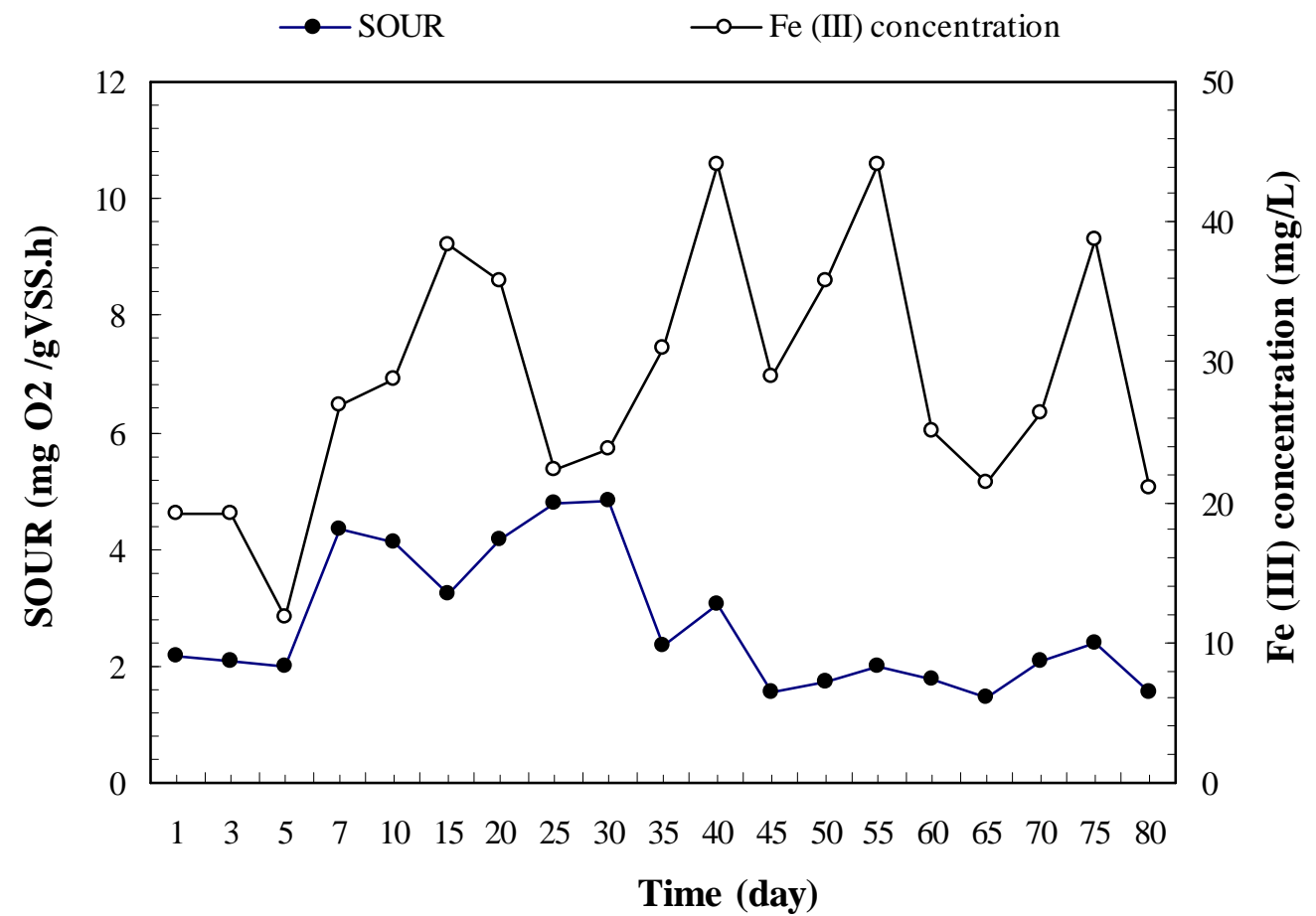

Fig. 2. Temporal variation of the SOUR and Fe (III) concentration of mixed liquor during the experiment. 


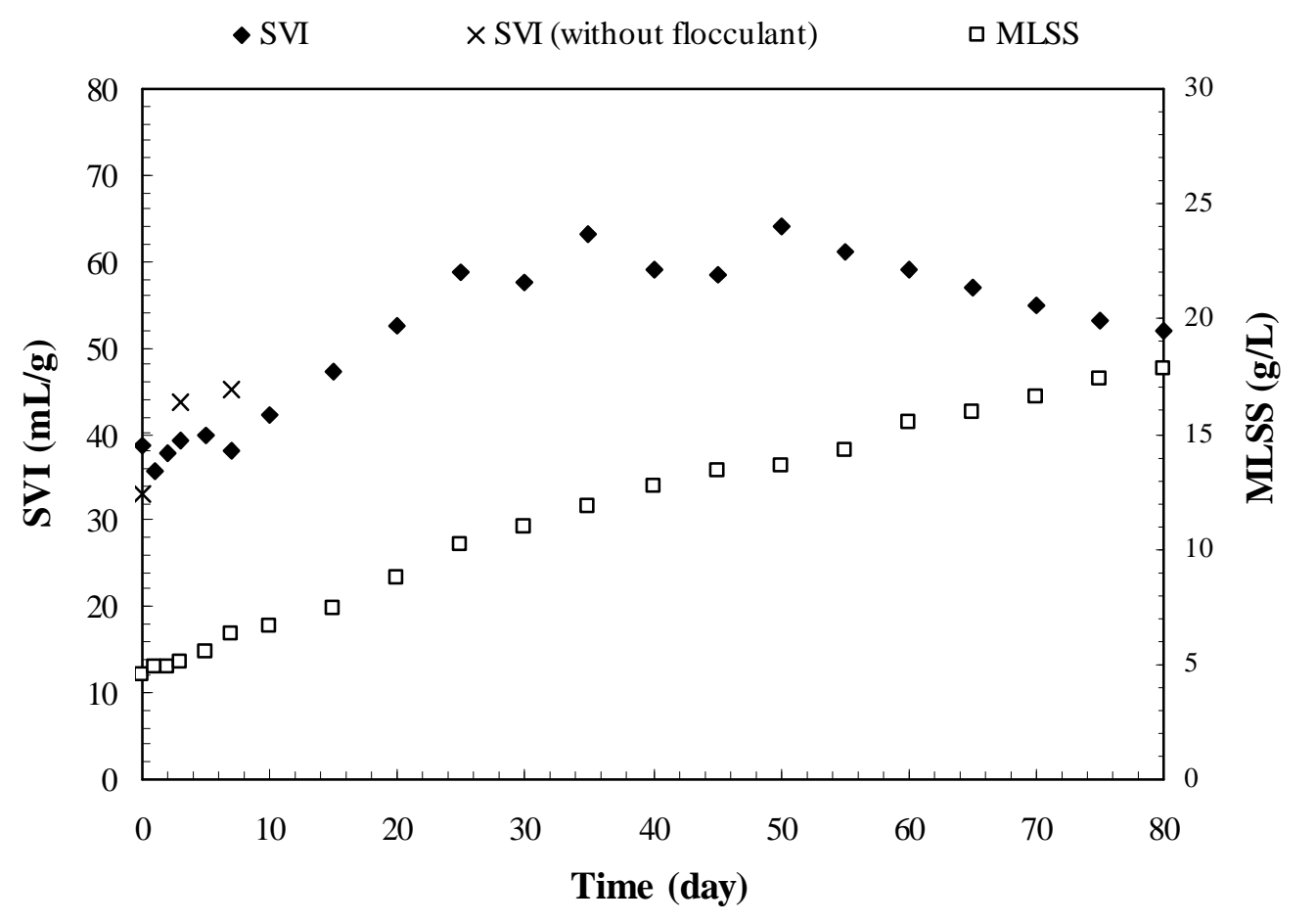

Fig. 3. SVI and MLSS profiles of the SMBR system 


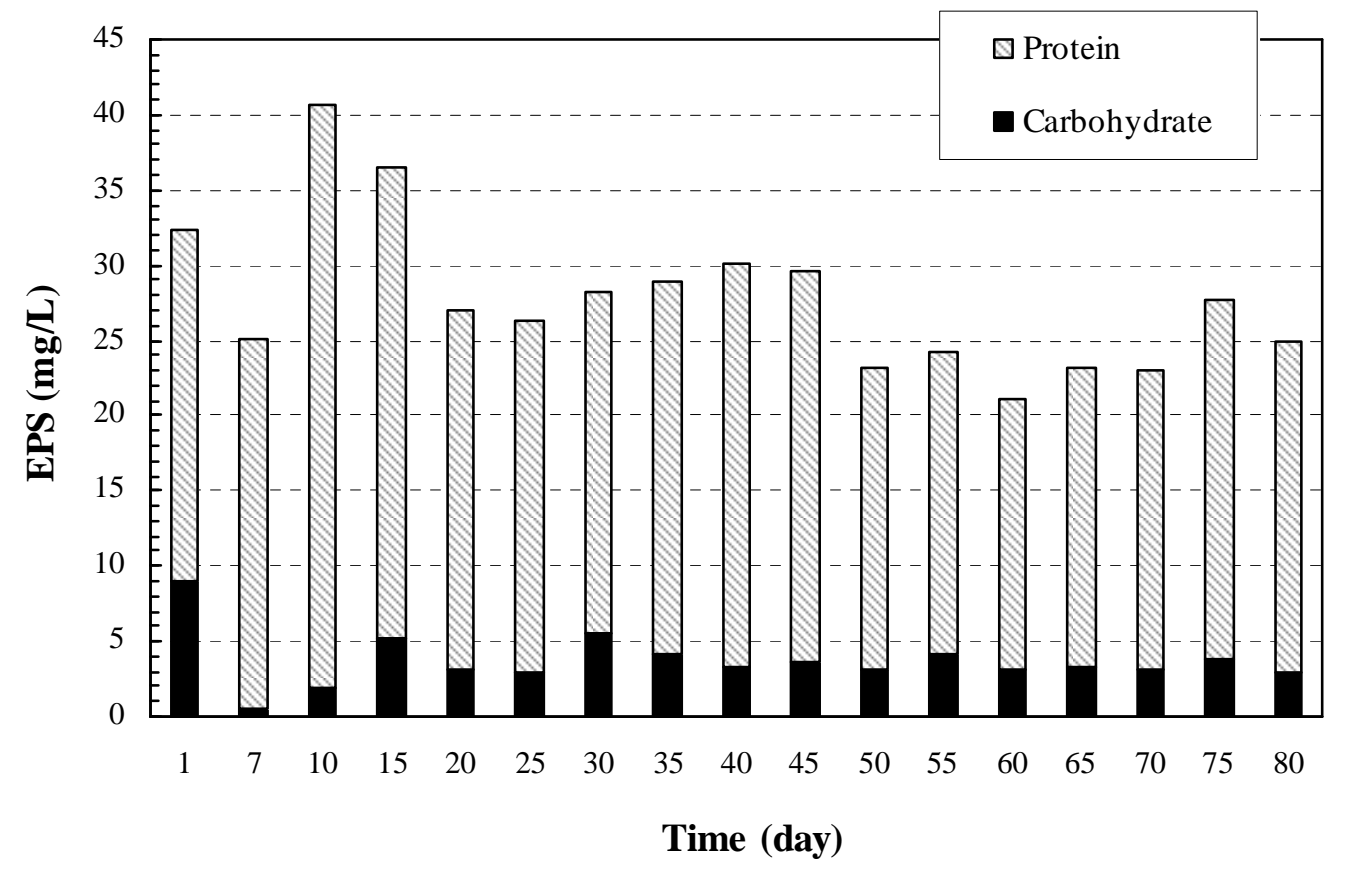

Fig. 4. Protein and carbohydrate concentration of soluble EPS 


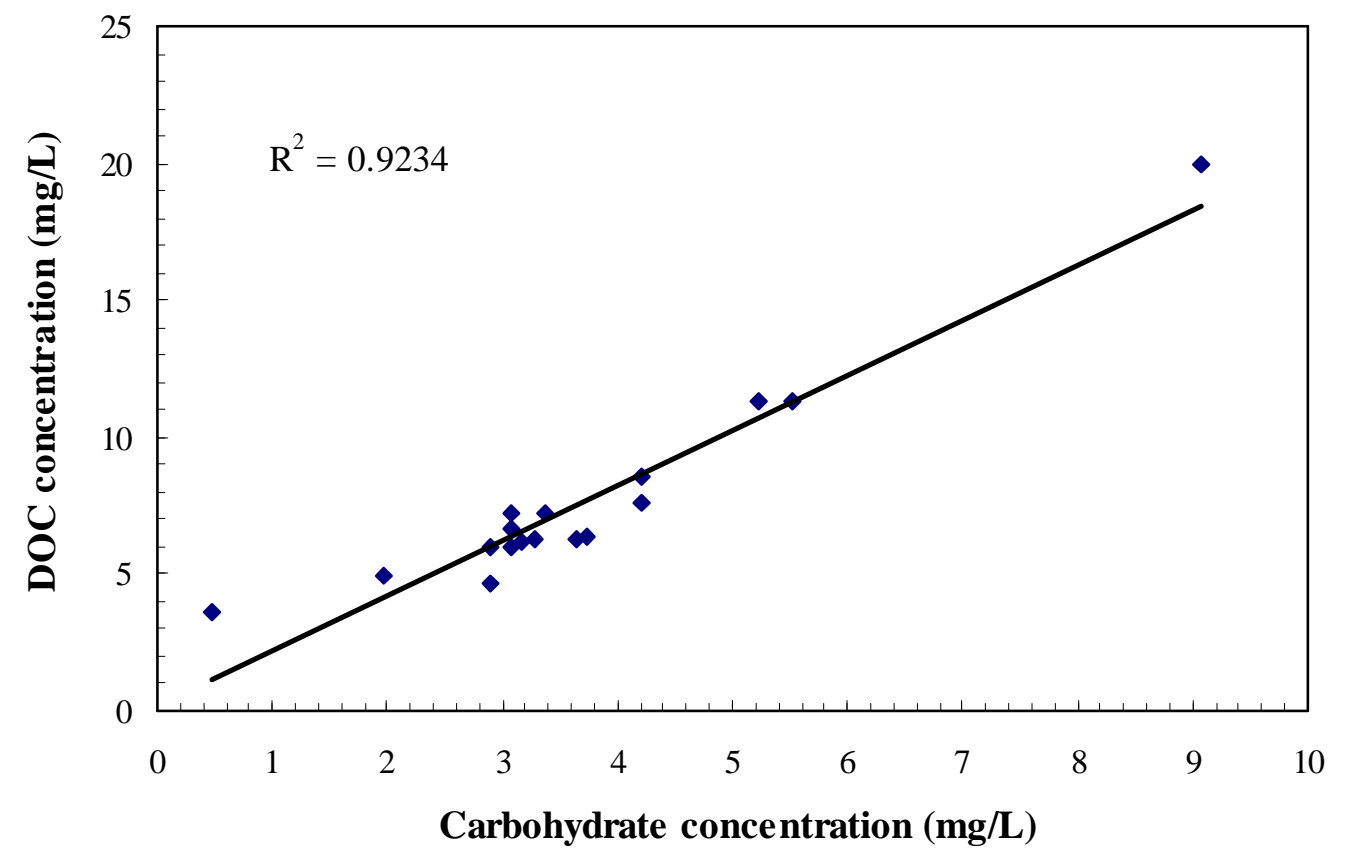

Fig. 5. Correlation of soluble carbohydrates and DOC in the supernatant 


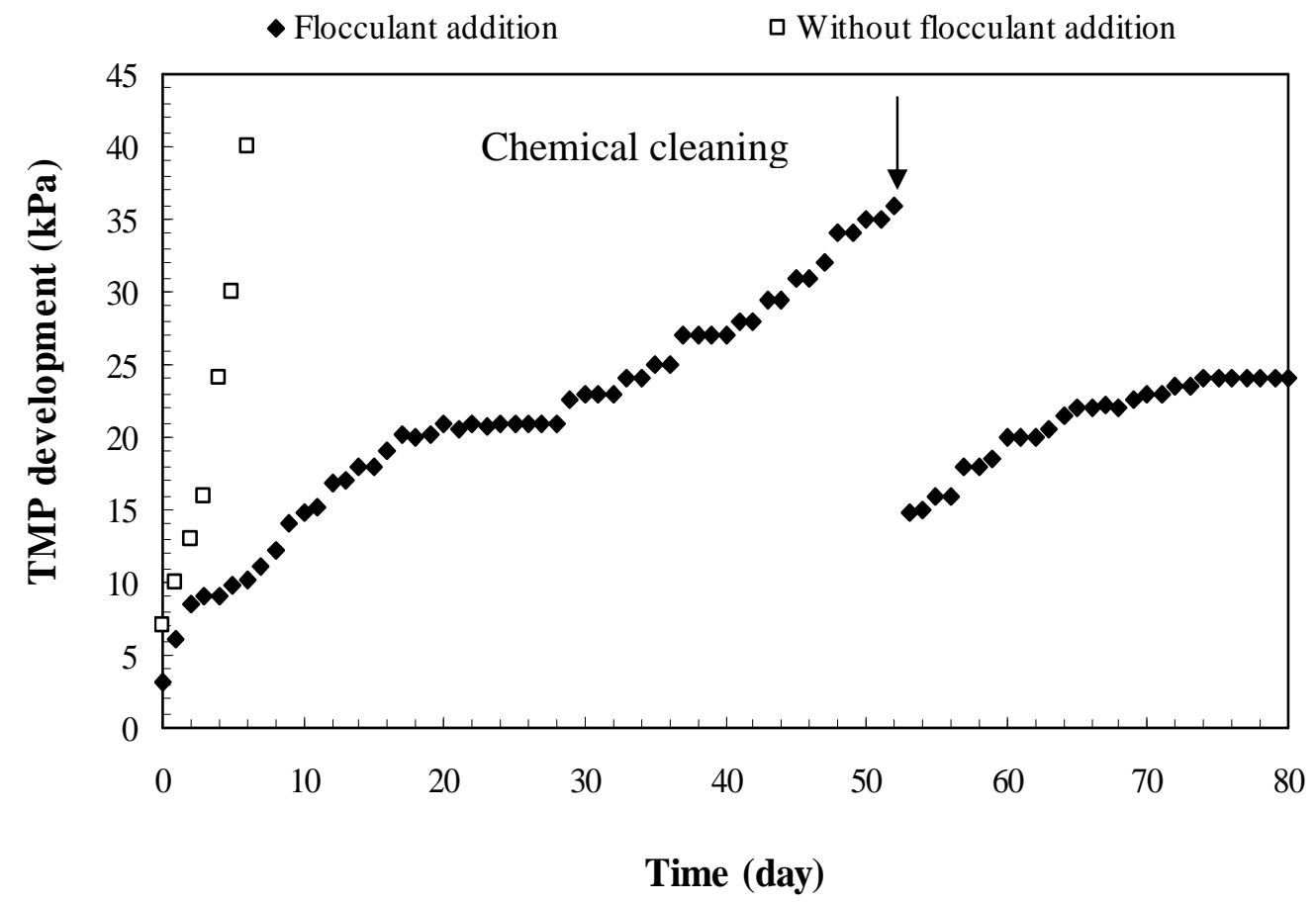

Fig. 6. TMP development of the SMBR systems with and without CIOF addition (Filtration flux $=12 \mathrm{~L} / \mathrm{m}^{2} . h$; backwash rate $=36 \mathrm{~L} / \mathrm{m}^{2} . h$, backwash 1 min every $1 \mathrm{hr}$ ) 